\title{
Usage of Social Media for 2019 Electoral Peace Campaign by Non- Governmental Organizations IN Kwara State, Nigeria
}

\author{
Kadiri Kehinde Kadijat \\ University of llorin, Nigeria \\ kadirikk0207@gmail.com \\ Kehinde Adetola \\ University of llorin, Nigeria \\ kennydee055@gmail.com \\ Tella Adeyinka \\ University of llorin, Nigeria \\ tellayinkaedu@yahoo.com \\ Raji Khalid \\ University of Ilorin, Nigeria \\ rajikhalid90@gmail.com
}

\begin{abstract}
There is a growing interest in the ways non-governmental organisations (NGOs) can ensure that electorates have access to information that could improve comprehension of the electoral process and reinforce tranquil relations between the electorates and political stakeholders. This study examined the usage of social media for 2019 electoral peace campaign by NGOs in Kwara State, Nigeria. The study adopted a qualitative research method and multistage sampling technique was adopted as sampling technique. The study focused mainly on four LGAs i.e. Asa, Ilorin South, Ilorin West and Ilorin East Local Government Areas. In these four LGAs, 15 NGOs with a vested interest in electoral peace campaigns were purposively selected. Unstructured interview was used to collect data from the social media handlers of these NGOs. The data collected were recorded and transcribed. The gathered data were arranged in themes following the approach of manual thematic analysis. Findings from this study showed that NGOs in Kwara State used social media for electoral peace campaign during the 2019 general elections. Facebook, WhatsApp, Twitter, Instagram and LinkedIn were the most used social media platforms among NGOs in Kwara State during the 2019 general elections; however, their level of usage is average. The motivation for social media usage among NGOs in Kwara State during 2019 general elections can be attributed to the wider coverage and reach of social media. Lastly, during the 2019 general elections, NGOs in Kwara State embarked on peace campaigns before elections, some do it during and few
\end{abstract}


do it post-electoral peace campaign. Among several recommendations, the study recommended that the electoral umpire in Nigeria, the Independent National Electoral Commission should include training of officers in their electoral briefings on the viability of social media use during elections by officers.

Keywords: Elections, Peace, Campaigns, Social Media, Electorate

\section{INTRODUCTION}

As indicated by Kemp (2019), the Internet audience grows by a million daily. There are 3.48 billion users of social media in 2019, with the figure skyrocketing by 288 million since 2018 (Kemp, 2019). Nigeria has experienced an exponential increment in the use of social media specifically and the Internet generally. From a humble 200,000 users in 2000, reports demonstrated that 98.39 million Nigerians utilize the Internet in 2019, with 54\% making use of it every day and 12\% (24 million) having active social media accounts (Udodiong, 2019). Figures like these stress the expanding prevalence and accessibility of social media networks and demonstrate that the manners by which individuals share information have changed drastically. Social media networks transcend nationwide boundaries, enabling users to have access to global information. The effect that social media currently have on how we get process and produce information is constantly developing, and associations/ institutions that utilize these new platforms of communication might be more successful in realizing their established goals.

Usually, electoral process is required to contribute towards the consolidation of democracy in any country. Via elections, the electorates are furnished with sufficient chance to vote for their preferred candidates for various political positions. In Nigeria, the electoral process has historically been characterized by electoral violence (Olowojolu, Rasaq, Ake, Ogundele \& Afolayan, 2019). Nigerians' understanding of the electoral process is pivotal to a serene political election. In that capacity, there is growing interest in the ways nongovernmental organizations can ensure that electorates have access to pertinent data that will improve comprehension of the electoral process and reinforce tranquil relations between the electorates and political stakeholders (International IDEA, 2006). Olaifa (2017) posits that NGOs assume a significant role in fostering trust in the electoral process, to induce policymakers and communicate with the general public via social media platforms.

Uzuegbunam (2013) insistently expressed that Non-Governmental Organizations (NGOs) are involved in peacebuilding exercises than most governmental agencies in Nigeria. Before, NGOs in Nigeria utilized the traditional media (radio, television), rallies/ street campaigns and door-to-door awareness marches in mobilizing electorates toward avoidance of electoral violence. However, in addition to the use of traditional media (radio, television), rallies/ street campaigns and door-to-door awareness, they have also embraced the use of social media to create awareness towards violence-free elections. The fast progression of social media networks has set forth ways for NGOs to impart the general population. The tremendous impact of social media, notwithstanding the presence of the traditional media, is a trend that numerous NGOs need adapt to if they need to stay relevant. This becomes important because the information consumption pattern of accessing, producing and consuming media has drifted drastically towards social media (Bartlett, Krasodomski-Jones, Daniel, Fisher, \& Jesperson, 2015). 
The 2019 Gubernatorial Election in Kwara State was bedevilled with intense rivalry. This was largely between the "O to ge" movements, All Progressives Party (APC) and the "Otun ya" movements, People's Democratic Party (PDP). Tensions were consequently high as the general public was often whipped into frenzies. However, the election was relatively peaceful, with very minimal occurrence of violence. In line with this, it is relevant to understudy the role played by the NGOs' in Kwara State during the 2019 electioneering vis-à-vis the usage of social media for peacebuilding in the state. This study wants to specifically understand the social media platforms used by the NGO for peace campaign during the election, the frequency of social media usage, the motivation for its usage and the season for the campaign. Studies in this respect are quite limited as majority of studies focus on political parties' use of social media to campaign peacefully and the ones that do address this area are yet to examine Nigeria as a study area.

\section{LITERATURE REVIEW}

Election is the bedrock of a certifiable democratic framework. Osumah and Aghemelo (2010) consider election to be a procedure through which individuals pick their leaders and make their preferred policies known, subsequently giving authority to an administration to rule. Roberts and Edwards (1991) cited in Omotola (2007) describe election as a strategy for choosing people to fill certain public posts through decisions made by the electorate; people who can cast a ballot under the laws of the electoral framework. Webster and Fallows (2006) characterize election to be the demonstration, procedure or technique of picking an individual or people through votes for public positions/offices backed by state authority.

As indicated by Albert (2007), electoral violence includes all types of organized demonstrations of threats intended to scare, hurt, or coerce the electorate or political rival pre and post-election with an expectation to decide or delay a political procedure. Ogundiya and Baba (2005) consider electoral violence to be a wide range of demonstrations, riots, party conflicts, political killings, plundering, thuggery, arson, spontaneous kidnappings or not, which happen pre, during and post-elections. Fischer (2002) characterizes electoral violence to be any irregular or premeditated act geared towards to deciding, postponing, or generally disrupting an electoral procedure via the use of hate speeches, physical ambush, disinformation, blackmail, assassination or decimation of property. Likewise, Igbuzor (2010), considers electoral violence to be any demonstration of violence sustained throughout electoral exercises, incorporating any of the following: utilization of thugs to disturb political gatherings, or the utilization of perilous weapons to scare or harm voters and other stakeholders.

\section{Electoral Violence in Kwara State}

In an attempt to obtain or retain political posts in Kwara State, certain political figures have made us of violence on the electorates and political rivals. One of the most vicious cases of electoral violence in Kwara State can be traced to the period preceding the 2003 governorship election, in which multiple people were killed, properties were demolished, and the harmony and security of the state were undermined (Human Rights Watch, 2007; Saliu \& Saka, 2006).

The electoral violence in Kwara State in 2003 was birthed by the unhealthy and cold relationship between Dr Abubakar Olusola Saraki and his alleged godson, the former governor of the state, late Rear Admiral Muhammad Alabi Lawal (Rtd). The contentions, 
intraparty at origin later transformed into inter-party when Dr Saraki left the All Nigeria Peoples Party (ANPP) for the People's Democratic Party (PDP) while his alleged godson, late Rear Admiral Lawal (Rtd) remained in ANPP. The conflict was fixated on the two political figures, the contentions and its repercussions had broad ramifications for harmony in the state. Tense and damaging was the violence to such an extent that the tale of electoral violence in the state would to a great extent be deficient without identifying with this event, where political opponents viciously battled for the control of the state (Sambo, 2005; The Punch Newspaper, 2003). Brutal conflicts were recorded among supporters of the political parties. The 'Maja' and 'Akaje' gangs, who were loyal supporters of the Saraki camp battled against the 'Gbosa Boys' of the Lawal camp (Ibrahim, 2002).

The fierce encounter between the supporters of the political rivals deteriorated severely such that in March 2002, issues, for example, the erection and removal of political billboards incited vicious conflicts (Sambo, 2005; Abdullahi, 2002). The most pronounced violence that happened in 2002 was in Ilorin, whereby supporters of both parties battled for five days, killing, mangling, and obliterating valuable properties. Another episode of electoral violence occurred when the National Pilot building was bombed, which was under the ownership of Dr. Bukola Saraki. The newspaper was an instrumental contributor to the Bukola Saraki campaign. Five employees of the company were genuinely harmed and the building was levelled in the explosion. The National Pilot management asserted that the act was done by the opposition party supporters (The Punch Newspaper, 2003; Ilor, 2002; Edemodu, 2002).

\section{Social Media in Nigerian Politics}

The utilization of social media in Nigerian elections became recognizable in the road towards the 2011 decisions, and now gets boundless media attention for engaging, informing and empowering Nigerians by and large (Bartlett, Krasodomski-Jones, Daniel, Fisher \& Jesperson, 2015). Twitter turned out to be the most prominent social media used during the 2011 presidential elections and it was also principally the traditional media's first trial of social media in Nigeria (Asuni \& Farris, 2012). The "IAmLagos" Facebook page brought people to the website, Twitter hashtag and call centre which proved very effective in improving social media coverage of polling units in Lagos with $80 \%$ coverage achieved during the gubernatorial elections (Asuni \& Farris, 2012). The rate of social media use for the 2015 election in Nigeria was strengthened as a consequence of improved manpower, economical mobile phones, and the people's increased accessibility to the Internet (Obono, 2016). In the development of the 2015 elections, the campaign efforts of the People's Democratic Party (PDP) were centred on social media largely employed to discredit the opposition party (APC).

During the 2019 elections, social media influencers assumed an overwhelming role on the result of the elections. Political parties contracted social media influencers to help plan, shape and oversee opinions and narratives on topical political issues and discourse. These influencers additionally advanced hashtags, for example, '\#NigeriaDecides2019', '\#ElectionDay', \#AtikuIsWinning, \#PMB4Plus4 and so forth, with the two popular candidates being the incumbent President Muhammadu Buhari of All Progressives Congress (APC) and Atiku Abubakar of People's Democratic Party (PDP). 


\section{Non-Governmental Organizations (NGOs) and Electoral Peace Campaigns}

NGOs are organized groups of people geared towards various purposes that connect with human aspiration and societal advancement. They can be set up to support a specific cause, for example, human rights, or to enact programs such as reducing illiteracy levels. Members of NGOs are usually recruited locally and globally and they are characterized by a social life that is voluntary, open, self-generating, self-supporting, with a set of shared principles (Charnovitz, 1997; Diamond, 1999). NGOs consist of people who act aggregately in the public sphere to air their goals and to impact policies. Therefore, NGOs are viewed as one of the fundamental indicators of democratic consolidation (Linz \& Stepan 1996) and are connected with developmental targets given its capacity to pool assets to improve institutions, infrastructures and general societal living standards (Diamond 1999).

Electoral peace campaigns involve the recognition and backing of measures required for change towards an increasingly peaceful association and government structures, to avoid a continuance of violence. Peace campaigns are likewise seen to be endeavours to overcome the social, cultural and structural inconsistencies causing conflict, particularly in support of peacekeeping and peacemaking. Motivations of peace campaigns are drawn from developmental imperatives confronting humans and conflict resolutions. Peace campaigns now have such a critical role in the world (Uzuegbunam, 2013).

With regards to elections and, election-based conflict specifically, NGOs have been perceived to have a critical task to carry out in advancing peace as it is less compelled by mandates, able to retain validity when conversing with several parties, and able to openly deal with the grassroots populace (Orjuela 2003). The contributions of NGOs are significant not just as far as the outcomes that are accomplished, yet also in light of the good faith that individuals may feel about NGOs stand for human rights. They are privately coordinated and managed, yet they additionally obtain strength from other societal members willing to support their cause.

\section{NGOs and Social Media Networks}

NGOs can encourage greater communal interaction for a range of purposes. Such interaction might be especially significant in the developing world, wherein numerous nations are striving towards the achievement of greater democracy while at the same time seeking to manage a past filled with violence. The tools and strategies NGOs use in achieving these purposes have extended altogether in recent times, particularly as social networking and greater Internet connectivity have turned out to be accessible to the wider world. NGOs are progressively associating with partners, volunteers, beneficiaries, and supporters by means of social media platforms, seeking to build social capital from the digital sector. Through the virtual civil society, NGOs can collaborate on the Internet to achieve cherished goals in a swifter and cost-friendly manner (Kittilson \& Dalton 2008).

Certainly, not all NGOs look to connect with partners through social media platforms. Some may stay away from social media as it leaves a digital footprint that might be unwanted and even unsafe for the NGOs and those interfacing with them - especially in areas with an oppressive government. In like manner, distributing the needed assets to manage web-based trolling and other demands of a social media presence may not merit the asset allotment to some NGOs with pressing demands on their hands, requiring immediate funding. Thrall et al. (2014) propose that social media exposure for NGOs experiences similar limitations 
as traditional media do, being beneficial only to NGOs with pre-existing networks and vast resources. Despite this, numerous NGOs are looking to foster greater social media presence.

For NGOs to construct solid connections in the society, it is significant that the NGO's target group is consistently engaged with. Previously, this has frequently happened through physical correspondence. Now, such collaboration is conceivable via digital means. There are numerous means that NGOs may now utilize when connecting with their target group. NGOs may provide data about their goals (through their website or platforms like Twitter or Facebook). In terms of social media use, one-directional sorts of correspondence have been criticized for not encouraging the kind of connection that is available in physical correspondence, as it fails to facilitate a reciprocal connection between the NGOs and its target population.

As a result of the failure to facilitate reciprocal connection, NGOs seek to complement website usage with other social media platforms, (for example, Twitter and Facebook). Such media are intended to permit users either to interact with content created by another user or to communicate by means of the making of their content. This is altogether different from websites - which in general is concerned with only providing information to passive visitors. Interactivity is especially touted as one of Twitter's key advantages, as it has been considered by some to be increasingly proactive as far as interaction is concerned - not only sharing information, yet also accelerating this function and becoming a source of information itself (DeMers, 2013).

Waters and Feneley (2013) examined social media platforms utilized by "The NonProfit Times top 100 associations". It was revealed that these organizations, to a great extent, prefer the use of websites for fostering relationship with possible stakeholders, and are less inclined to completely make use of social media platforms. Waters et al. (2009) examined the 275 NGOs and their use of Facebook, finding that these NGOs failed to completely use different functions of the platform, for example, upload of media files. Further, they found that NGOs failed to give the various ways to their supporters could become progressively engaged with the goals of the NGOs; painting a picture of reduced interactivity.

In their investigation of social work NGOs' websites, Edwards and Hoefer (2010) find that these organizations hardly utilize social media for purposes related to advocacy, and when they used them, had no great effect. Lovejoy, Waters and Saxton (2012) in their study examined 4655 tweets from 73 NGOs, revealing that these NGOs are fundamentally utilizing tweets for a one-way conversation. The study revealed further that under $20 \%$ of tweets exhibited direct conversations with users, and that about $16 \%$ had indirect associations with users. These discoveries propose that NGOs are not interactively using Twitter. Guo and Saxton (2014) in their study examined the use of social media by 188 NGOs. They locate that an enormous level of these NGOs uses Twitter (79.79\%), Facebook (86.70\%), and YouTube $(71.81 \%)$, with an aggregate of $93 \%$ of NGOs in the analysed data utilizing some form of social media platform.

Utilizing Lovejoy, Waters and Saxton's (2012) sample, Guo and Saxton (2014) analyzed 750 haphazardly picked tweets from these NGOs. They discovered that practically $69 \%$ of these tweets give information regarding the NGOs' exercises and events, facts or reports that may be significant for the NGOs' partners. In this way, most of the tweets were not interactive, and merely gave updates to the users. Also, 20\% of the chosen tweets encouraged the provision of an online network. Then, the remaining $12 \%$ of tweets endeavoured to get 
supporters to accomplish some activities related to the NGOs' goals. It can be consequently seen that majority of these tweets were utilized in an increasingly passive manner - just giving information, failing to completely use the capacity of social media to make a progressively interactive web community

\section{METHODOLOGY}

The study was carried out in Kwara State, Nigeria. Kwara is located within the North Central geopolitical zone, commonly referred to as the Middle Belt. The primary ethnic group is Yoruba, with significant Nupe, Bariba, and Fulani minorities. The study adopted a qualitative design. This was opted for in a bid to allow the gathering of in-depth information from the targeted population. This served in providing details regarding human acts in such a manner that a quantitative design lacks. The study adopted a multistage sampling technique in the selection of respondents. First, cluster sampling was used in the division of local government areas into four: Asa, Ilorin South, Ilorin West and Ilorin East Local Government Areas. Then, purposive sampling was used in the selection of 15 NGOs with vested interest in electoral peace campaigns. The NGOs which were purposively chosen met the criteria of being registered, having social media visibility for her general operations, carrying out electoral peace campaigns, NGOs who operated at least in 2019 general elections and who have given their consent for an interview session. In a scenario in which the NGO's Executive Director was not available, the social media handlers stood in for them. At the end of the data collection process, ten Executive Directors and five social media handlers were interviewed.

The study adopted unstructured interview in the collection of data. This allowed for greater flexibility, granting the ability to respond to information, adjusting the guide as issues came up in the field. At every stage of the interview, the informants were allowed to opt-out of the research. Consent forms were duly written and signed by each informant. At this stage, the informants were also assured that the information provided would strictly be used for research purpose.

The data collected were recorded and transcribed. The gathered data were arranged in themes following the approach of manual thematic analysis. Thematic analysis was adopted because it offers a comprehensive process for the researcher to identify numerous crossreferences between evolving themes and the whole data (Hayes, 1997). It is also necessary for allocating a narrative for the diverse data to gain a clear understanding into the thoughts and experiences provided in the data because all possibilities for interpretation is possible in the thematic analysis (Alhojailan, 2012). Hence, thematic analysis was done because of the opportunities of comparison of data, establishing relationships and interpretations.

\section{FINDINGS}

The findings are presented under four themes. The four themes are as follows: social media platforms, frequency of social media usage, motivations for social media use, campaign season.

\section{Social Media Platforms}

Social platform is a web-based technology that enables the development, deployment and management of social media solutions and services. It provides the ability to create social 
media websites and services with complete social media network functionality. Against this backdrop, the researcher sought information on the social media platforms used amongst the NGOs interviewees. Majority of the informants made use of Facebook as a platform to drive the electoral peace campaign agenda. Specifically, one of the informants explained that "Facebook is a community for all manners of people, reaching your target audience has more possibility". This assertion vividly showed that Facebook is a platform that accommodates all and sundry and at least if not all, a higher segment of the target audiences are reached with this medium.

Informant 9 added that political novices particularly young ones could be easily reached on Facebook while matured professionals can be assessed on LinkedIn platform. One of the informants agreed with the above suggestions by succinctly stating that the rationale for using Facebook is because it is the most frequently used platform by different spectrum of people from different walks of life.

The obtained data also revealed that only two informants made use of twitter in their electoral peace campaign. Informant 5 admonished that Twitter was used because it was a serious platform for informed people: "Twitter is a formal platform used basically by intellectuals". Similarly, Informant 9 shared the view of informant 5 on this point by stating that even though Facebook is largely used for electoral peace campaign, there were situations when Twitter became the most preferred. He emphasized by stating succinctly that "If I want to do a video promotion, it will not make so much sense on Facebook like using it would on twitter". The inferences from these statements show that Twitter is considered as a good space for constructive discussions and video promotions.

In addition, it was revealed that most of the informants $(2,3,4,6,9,11,13$ and 15) make use of Instagram. According to them, the compelling photography capability of Instagram made it almost impossible for such medium to be ignored by its target audience. Also, the photography efficacy made it almost easy for the message to make a resounding impact on people. Specifically, Informant 9 stated that young people particularly ladies are predominantly the users of Instagram, therefore it was always deliberately used to target them. While others informants who use Instagram expressed that it has a high aesthetic appeal to their target audience. According to them, peace campaign doesn't have to be in only formal environments, it can be chipped in even in the midst of fun.

Another social media platform that was highly used by the informants was WhatsApp. According to them, WhatsApp was frequently used to communicate peace campaign messages during election periods because of its personal appeal and the direct impact it has on the recipients. The effectiveness of WhatsApp as a medium of reaching out to the people was succinctly couched by informant 5: "WhatsApp has a great personal appeal, hence making it easy to effectively communicate with their different stakeholders". Informant 14 stated that "Whatsapp is relatively accessible; we have so many groups to reach so WhatsApp makes it easy to pass messages across to groups. We have women groups, different community groups". Emphasizing on the ability of WhatsApp to send messages to many groups, Informant 10 opined that she would rather stick to Whatsapp for electoral peace campaign because it seems to be the easiest and most affordable. Another informant explained that the ease that comes with Whatsapp use, its accessibility and its ability to reach many groups at a time made it a unique communication channel to their various stakeholders. 
The data in the study revealed that LinkedIn is the least used platform for electoral peace campaign. It was only Informant 9 that used LinkedIn for electoral peace campaign. Many of the informants explained that their target population are not domiciled on LinkedIn since it is a hub for experts and professionals. This submission revealed that majority of the target audience of these NGOs is not professionals. Hence, the platforms used are audience-driven.

Following the aforementioned, it is evident that Facebook is the most used social media platform amongst NGOs in Kwara State while LinkedIn is the least used.

\section{Frequency of Social Media Usage}

Another theme of this study is the frequency of social media usage by the NGOs. Frequency has to do with how aggressive the NGOs personnel make use of social media to push the peace advocacy agenda to their target audience. From the interviews conducted, it did emerge that majority of the informants actually focus on using social media for electoral peace campaign. The perception of the informants on each social media handle determined how each medium was frequently used.

A number of views emerged that some NGOs depend heavily on the use of social media for the crusade of their electoral peace campaign. Informants 3, 6, and 9 admitted that they maximally use social media for advocacy on electoral peace campaign and it has been the tool they have been using since inception. Informants 1, 2, 4, 5, 11, 13, 14 use social media for electoral peace campaign on a moderate level; because they just recently got exposed to the capability of social media for electoral peace campaign. Before now, they used other campaign vehicles but recently they got acquainted with the use of social media. Informants 13 admitted that her NGO just started using the social media for peace advocacy quite lately and the NGO is just getting familiar with the trend.

The data in the study also revealed that Informants 10 and 15 use social media minimally for electoral peace campaign. Informant 10 explained that her NGO basically use two social media platforms but has great expertise in only one platform for all the NGOs routines. When she was asked the rationale behind the scanty usage of the social media, this informant explained that she is not technologically savvy in the usage of new media hence the reason for the restriction to her comfort zone. Then, the other two informants revealed that they have never used social media for electoral peace campaign at all. Informants 7 and 13 explained that although they have social media accounts as an organization, they do not employ social media for electoral peace campaign. Informant 7 emphasized that the decision not to use social media for electoral peace campaign is hinged on the basis that he does not consider social media as a relevant tool for reaching the target audience. While Informant 12 stated that the organization has not used it due to poor skills set of personnel handling social media handles.

\section{Motivations for Social Media Use}

Motivation means needs, desires, wants or drives within the individuals. It is the process of stimulating people to actions to accomplish goals. In the work goal context, the psychological factors stimulating the NGO's attitude for social media users need to be understood.

The data from the interviews conducted showed that the NGOs consider their target audience before choosing the social media handles that they utilise for electoral peace 
campaign. Majority of the informants use social media because they believe that at least one of their major target audiences would be reachable via social media.

Furthermore, the data in the study revealed that the main target audience for electoral peace campaign are youths and the best spot to reach them is through the social media handles. Similarly, Informant 15 explained that most of the target audience is the youth and they can be easily reached through social media vehicles. Informant 9 corroborated this by stating, "We discover from data and statistics that we need to reach young ones where we can see them in mass. While they are catching fun, we pass our message across".

Another informant stated women as another segment of their target audience. It was cited that women are one of their priority audience because of their charisma in influencing decisions of people. These informants unanimously agreed that the best way of reaching women is through social media. To reach these set of influential women, Informant 10 explained that she is a member of at least six women groups on WhatsApp.

While some informants considered target audience reach as a motivation for adopting social media, one of the informants think otherwise. Informant 7 believes that although the organization focuses on youths and women, a large number of them cannot be reached on social media, therefore, he has no motivation for using the social media for the electoral peace campaign.

Asking the informants about how they reach people at the grassroots on social media, one of the informants explained that to be one of the major challenges in the usage of social media for electoral peace campaign. However, another informant explained that he was able to reach people at the grassroots but they are negligible. However, he reiterated that those negligible few people are still significant in making an impact on people because they are leaders.

Another aspect that informants mentioned spontaneously when describing their motivations for using social media was the cost, access and ease of using social media by them and also their target audience. Unlike traditional media that require an appreciable amount of money to plan and execute, social media peace campaign on social media is cheap and effective on the social media platform. One of the informants explained that traditional media is very expensive and might not reach the target audience too.

Furthermore, the data from this study showed that the ease of use of social media was also another rationale for using social media for electoral peace campaign. Informant 3 explained that from the comfort of his office, he can come up with different strategies on electoral peace campaign compared to other traditional media that entails a lot of leg walks. The speed at which the messages on social media spread was also another motivation why social media was preferred by the informants. The possibility of the messages going viral is one of the advantages that social media has over other means of communication especially the traditional media.

What became noticeable during the interviews with the informants was that some organisations just prefer to publicise their social media handles irrespective of whether or not they have any Electoral Peace Campaign information to pass across. The bandwagon effect was one of the rationales for using or having social media handles irrespective of whether they are active or not. One of the informants explained that the majority of them do not have adequate knowledge on social media marketing hence there is a need for aggressive education on it 
While some informants have admitted that they just had to do electoral peace campaign on social because that is what is trending, few other informants use social media because there is virtually no point going outside the social media for advocacy in this contemporary times. In fact, Informant 9 considers the adoption of social media in this dispensation as a must. He categorically stated that "Why should we be talking about the motivations of social media for electoral peace campaign in this generation? How else do you want to do it better?"

Another motivation for using social media for electoral peace campaign was attributed to confidentiality. Being a political issue, many may be sceptical about criticisms but on social media, even shy people, those with speech latency and others who may be afraid of been apprehend can voice out their views.

\section{Campaign Seasons}

The data from the study showed that usage of social media for electoral peace campaign varies depending on the season of the election. According to the 13 informants who have adopted social media for electoral peace campaign, it was reiterated that their peace campaigns usually take place before the election. The informants acknowledged that the best time to start election campaigns is before elections campaigns start because that is when electoral violence are usually hatched against rival groups. One of the informants succinctly explained that the peace campaign is effectively done at the stage, there is no much to fear because the atmosphere has been set right. Informant 5 puts it this way "Basically, our campaign is before elections, we rely on what we have done before elections to still have effects on the electorates during and after elections". Some of the informants found out that during this season, the work is enormous as the terrain is usually tensed.

The tension in the atmosphere made some NGOs intensify efforts at peace communication. Informant 13 revealed that reactions from many corners of the state made it important for an increase in advocacy on election peace campaign. He stated that since January 2019 there was practically no day that he doesn't post on social media on election peace campaign because of the negative reactions gotten from the audience. Another informant also explained that peace campaign starts at the election registration process. He argued that people need to be sensitized on why they should be properly registered and how to avoid possible causes of disenfranchisement. According to him, if an uninformed electorate is disenfranchised, it can stir violence.

Corroborating this, linformant 9 said peace campaign is a necessity before elections. He stated emphatically that peace campaign should start as soon as the whole electoral process begins. He emphasized that election is not an event but a process hence it is important to educate electorates on election procedures to avoid election crisis or sabotage. He added that most election violence is orchestrated before elections therefore it is germane to do peace campaign because that is the season for violence planning and strategy. The above submissions showed that campaign for peace is usually very strong and very pronounced before elections.

Data in the research also showed that electoral peace campaigns were also carried out by informants during the elections. As the long-awaited election dates become reality, some of the NGOs still made efforts to preach and maintain peace during the election. Few informants explained that although they do electoral peace campaigns during elections period it was not pronounced as the wave became reduced. As observed earlier, many of the informants 
consider the pre-election peace campaign as the most important believing the effects span through the election period and even after. However, reiterating the need for electoral peace campaign during elections, informant 9 explained that most election violence mostly takes place during or after the counting of the ballot papers when a major party realised that they have lost elections.

Informant 9 added that many of the informants that served as monitors and observers in the 2019 general elections were duly trained before the election which naturally means that a higher level of decorum is expected from them during the election, however, this is mostly proven wrong. Therefore, he explained that one of the ways to keep the observers in check was to keep advocacy against election violence in all its ramifications vibrant online

The responses of the informants showed the need for electoral peace after elections. Generally, peace campaign after elections is not rampant. NGOs relax too because they expect the seed they have sown before elections to still yield after elections but informant 9 thinks otherwise "After elections, some fractions are not comfortable with the result so their reactions may be laced with violence". Few other Informants also agree that there are peace messages that will be of utmost necessity after elections. When asked about the kind of information campaigned after elections, Informant 8 said, "After elections we tell losers that their time will come".

Informant 3 added that the completion of elections is not the end, a coalition of NGOs do an appraisal of the elections and draw out issues. The confab is to help do a cursory analysis of the just concluded elections where they decide the need for post-election peace campaign and the extent to which it is needed "Then after the elections, we NGOs will meet, do analysis of the last election and share online our thoughts to still maintain peace".

Although some informants acknowledged the possibility of post-election violence but they did not engage in post-elections peace campaign because they saw no need for it given the relatively peaceful election that was conducted. For instance, Informant 11 said, "We know that violence can be before during and even after elections but pre-election period basically and during election is when we do electoral peace campaign". Informant 5 also said "Kwara is so fortunate maybe we would have argued if we were told that the transition in Kwara state will be this peaceful. There appeared as if there was no need for post-electoral post peace campaigns."

Informants 6, 8 and 13 opined that their peace campaign on social media is neither seasonal nor occasional. They explained that election peace campaign should be an all season campaign. According to them, electoral peace cannot be achieved with a fire brigade approach.

\section{DISCUSSION OF THE FINDINGS}

Based on the data collected for the study, it is evident that as a result of the usage of social media among NGOs in Kwara State, the NGOs in Kwara state make use of social media for electoral peace campaign. This is incongruent with the position of Saxton and Nah (2009) who noted that the rapid diffusion of social media applications ushers new possibilities for NGOs to engage the public, hence, adoption of social media is a trend that many NGOs will want to align with using possible channels to achieving this goal. However, there is a perception of social media inadequacy in carrying out peace campaign in Kwara State, due 
to the uniqueness of the environment, hence the reason why two NGOs in Kwara State did not use social media for their electoral peace campaign.

Also, Facebook, WhatsApp, Twitter, Instagram and LinkedIn are the most commonly used social media platforms among NGOs in Kwara State and their usage was based on the uniqueness and the ability of each of the platform to aid the campaign of electoral peace. For instance, Facebooks was used because it is the biggest social media site with larger users; Whatsapp was chosen because of ease in use and in communicating to groups; Twitter was used because of the serious terrain and the calibre of personalities who uses it. However, only one NGO make use of LinkedIn for electoral peace campaign because of their needs to reach out to professional people. The disparity in the usage of different social media platform is largely dependent on the distinctive features of the social media apps.

Findings from this study revealed that the motivation for the use of social media by NGOs are largely due to the ability of the social media to reach the youths who they consider the most germane target audience; the speed of dissemination of messages to a varied and large audience; cost-effectiveness and ease of use as compared with the other campaign vehicles.; and the justification that social media is an advancement in communicating peace. This finding is incongruent with Saxton and Nah (2009) who noted that the rapid diffusion of social media applications ushers new possibilities for NGOs to engage the public, hence, adoption of social media is a trend that many NGOs will want to align with and adopting possible channels to achieving this goal. In addition, the ability of the social media to reach the youths and the speed of dissemination of messages through social media to a varied and large audience is supported by Startcounter (2019) who reported that social media statistics of Nigeria as at May 2019 shows that over 1.3 million use the social media in Nigeria. However, poor Internet access and data cost are impediments to the use of social media among NGOs in Kwara State.

In Nigeria, the electioneering period constitutes party primaries season, campaign season, the actual voting season and announcement of results season. While most NGOs do peace campaigns before elections, some do it during and few do it after. The NGOs in Kwara State noted that embarking on peace campaign during any of these seasons can be dangerous as they are often time characterised with violent. This is corroborated by Nwadiebe and Dart (2010) assertion. Nwadiebe and Dart (2010) assert that party primary season, campaign and the announcement of results have been among the most violent periods in previous election cycles. However, majority of the NGOs in Kwara State identified pre-electoral seasons as the most sensitive period of elections when peace campaigns should be intensified. This is supported by Abatudu and Obakhedo (2009) who opine that pre-election campaigns, electiontime, and post-elections periods are usually violent, with campaigning in many areas beset by political killings, bombings and armed clashes between supporters of rival political factions.

Also, Abutu and Obakhedo (2009) opine that pre-election campaigns, election-time, and post-elections periods are usually violent, with campaigning in many areas beset by political killings, bombings and armed clashes between supporters of rival political factions. NGOs have identified pre-electoral seasons as the most sensitive period of elections when peace campaigns should be intensified. However, few NGOs have seen the need to go beyond the pre, during and post-electoral peace campaign to carry out what they called all-season electoral peace campaign. The data in this study revealed that violence and malpractices of election are effects from a crashed system, all-season electoral peace campaign will help to 
prepare the ground. This is in tandem with Annan (2014) when he stated that when conflict or violence occurs it is not as a result of just an electoral process. It is the breakdown of an electoral process and recommended peace education carried out by peace activists and educators consistently. The NGOs who do all season electoral peace campaign has set their hearts to see that the state is in constant peace. A build-up of dissatisfaction, oppositional forces and long term planning is the reason for electoral violence; the manifestation only heightens at the point of power transition which is the election period.

\section{CONCLUSION}

The electoral peace campaigns in Nigeria results from five inter-related factors: the ideal of orderly elections and potential to instrumentalize peace encourages NGOs to invest their time and energy in such campaigns; a fear that elections will descend into violence guarantees a responsive public; the difficulty of addressing the underlying drivers of violence encourages an individualization of responsibility. Thus, this article has been able to justify the need for electoral peace campaigns in Nigeria and underscored how peace campaigns have been so durable precisely because they have been driven with social media applications such as Facebook, Twitter, Instagram and WhatsApp.

The appreciable number of NGOs using social media for electoral peace campaign was birthed by the opportunities that social media affords vis-a-vis speed, wider reach, ease of use and multifaceted audience. However, few NGOs would not adopt social media for electoral peace campaign because it is perceived to be inefficient for electoral peace campaign in the State. The inefficiency of social media is spelt out in its inability to reach the interiors, illiterates and the financially disadvantaged people which form a large percentage of the population. But the argument that social media reaches at least a fraction of all target audiences in the state prevailed. Insight into the various audiences of NGOs in electoral peace campaigns revealed that most of the NGOs focus on youths both in the city and in the interior, the women, the vulnerable, Political parties' leaders and politicians, religious and traditional leaders.

\section{RECOMMENDATIONS}

Based on the finding of this study, the study recommends that the electoral umpire in Nigeria, Independent National Electoral Commission should include training of officers in their electoral briefings on the viability of social media use during elections by officers. Also, political parties should be actively involved in peace campaigns and not maximize social media just for their political reasons. More so, the constructive use of social media for informed and patriotic reasons and need for electoral peace should be entrenched in the school curriculum particularly ICT and Civic Education in the junior and senior secondary schools. The government should understand that peacebuilding is also a political undertaking, not just a humanitarian one; hence, they should intensify involvement in peace campaigns. The government is supposed to be at the forefront when it comes to the campaign against violence and they should work at achieving this by any means possible. In addition to the use of social media for electoral peace campaign, NGOs should make use of every other available medium of communication such as radio, television and newspaper for their peace campaign. Areas of further studies may delve into the impact of social media use for electoral peace campaign. This study did not cover the social media strategies used for peace campaign. 
However, NGOs should continue to engage their social media handlers and member in capacity development that would boost their social media literacy and competence.

This study has shown that social media, in particular, are pervasive in everyone's personal, professional and political lives because it is a set of competencies that empowers citizens to access, retrieve, understand, evaluate and use, create as well as share information and media content in all formats, using various tools, in a critical, ethical and effective way to participate and engage in personal, professional, political and societal activities. Therefore government and NGOs should engage their social media handlers and member in capacity development that would boost their social media literacy and competence. This would help them to create a media and information literate person who would not only be a consumer of information and media content, but also a responsible information seeker, knowledge creator and innovator, who is able to take advantage of a diverse range of information and communication tools and media.

\section{REFERENCES}

Abatudu, M., \& Obakhedo, N. O. (2009). Mandate theft and retrieval: The 2007 governorship election in Edo State. In J. Ibrahim, \& O. Ibeanu (Eds.), The 2007 Nigerian elections and subversion of popular sovereignty (pp. 235-264). Abuja: Center for Democracy and Development.

Abdullahi, B. (2002, April 12). Kwara: The fire this time. This Day Newspaper. https://www. ilorin.info/fullnews.php?id=393

Annan, N. (2014). Violent conflicts and civil strife in West Africa: Causes, challenges and prospects. Stability: International Journal of Security and Development, 3(1). Doi. 10.5334/ sta.da

Asuni, J. B. \& Farris, J. (2012). Tracking social media: The social media tracking centre and the 2011 Nigerian elections. Abuja: Shehu Musa Yar'Adua Foundation.

Bartlett, J., Krasodomski-Jones, A., Daniel, N., Fisher, A. \& Jesperson, S. (2015). Social media for election communication and monitoring in Nigeria. London, UK: Demos.

Charnovitz, S. (1997). Two centuries of participation: NGOs and international governance. Michigan Journal of International Law, 18 (2), 183-286.

DeMers, J. (2013). Twitter vs. Facebook: how do they compare? The Blog, Huffpost. Available online at http://www.huffingtonpost.com/jayson-demers/twitter-vs-facebook_b_3869786. $\mathrm{html}$.

Diamond, L. (1999). Developing democracy: Toward consolidation. Baltimore: The Johns Hopkins University Press.

Edemodu, A. (2002, December 29). Year of assassins and political violence. The Guardian Newspaper.p 20.

Edwards, H. R., \& Hoefer, R. (2010). Are social advocacy groups using web 2.0 effectively? Journal of Policy Practice, 9, 220-239.

Guo, C., \& Saxton, G. D. (2014). Tweeting social change: How social media are changing advocacy. Nonprofit and Voluntary Sector Quarterly, 43(1), 57-79. Doi: $10.1177 / 0899764012471585$ 
Human Rights Watch. (2007). Criminal politics, violence, "godfathers", and corruption in Nigeria. Human Rights Watch Report, 19 (16A). https://www.hrw.org/reports/2007/nigeria1007/ .

Ibrahim, S. (2002, April 12). Thugs unleash terror in Kwara This Day Newspaper. p. 17.

Ilor, D. (2002, December 17). 7 killed in PDP/ANPP clash. This Day Newspaper. https://allafrica. com/stories/200302240461.html

International IDEA (2006). Electoral management design: The International IDEA Handbook. Stockholm: International IDEA.

Kemp, S. (2019). Digital 2019: Global digital overview. Datarepotal. https://datareportal.com/ reports/digital-2019-global-digital-overview

Kittilson, M. C, \& Dalton, R. J. (2008). The Internet and virtual civil society: the new frontier of social capital. UC Irvine: Center for the Study of Democracy. https://escholarship.org/ uc/item/2cj1c67k

Lewis, D. (2009). Non-governmental organizations, definition and history. In H. K. Anheier \& S. Toepler (Eds.) International Encyclopedia of Civil Society, (pp. 1-6). http://personal. lse.ac.uklewisdimagesencylcivilsocietyngos-dl.pdf.

LinkedIn (2019). LinkedIn - About. LinkedIn. Available online at http://press.linkedin.com/ about/

Linz, J. J. \& Stepan, A. (1996). Toward consolidated democracies. Journal of Democracy 7(2), 14-33.

Lovejoy, K., Waters, R., \& Saxton, G. D. (2012). Engaging stakeholders through twitter: how nonprofit organizations are getting more out of 140 characters or less. Public Relat Rev, 38, 313-318.

Obono, K. (2016). The architecture and use of social media in the 2015 Nigerian general elections. The Nigerian Journal of Communication 13(1), 47-78.

Olaifa, O. (2017). Curbing violent extremism through peace building in Nigeria. Journal of US-China Public Administration, 14(4), 221-223. Doi:10.17265/1548-6591/2017.04.004.

Olowojolu, O., Rasaq, B., Ake, M., Ogundele, O. \& Afolayan, M. (2019). Trends in electoral violence in Nigeria. Journal of Social Sciences and Public Policy, 11(1), 37-52.

Omotola, J. S. (2007). Godfathers and the 2007 Nigerian general elections. Journal of African Elections. 6(2), 134-154.

Onwudiwe, E \& Berwind-Dart, C (2010). Breaking the cycle of electoral violence in Nigeria. United States Institute of Peace, Special Report 263, p. 2.

Orjuela, C. (2003). Building peace in Sri Lanka: A role for civil society. Journal of Peace Research 40 (2), 195-212.

Osumah, O. \& Aghemelo, T. (2010). Elections in Nigeria since the end of military rule. AFRICANA. 4 (2), 9-39.

Policy and Legal Advocacy Center (2011). Social media and the 2011 elections in Nigeria. http:// www.placng.org/new/publications/Social\%20Media $\% 20$ and $\% 20$ the $\% 202011 \% 20 \mathrm{E}$ lections\%20in\%20Nigeria.pdf.

Saliu, H.A. \& Saka, L. (2006). Electoral process, electoral violence and national security: the Nigerian experience. Ilorin Journal of Sociology, 2(2), 1-11.

Sambo, Z. S. (2005). Political conflicts and urban violence in Ilorin. In H.A. Saliu (Ed.) Nigeria under Democratic Rule, 1999-2003, Volume Two, (pp 7-18). Ibadan: University Press. 
Saxton, G. D. \& Nah, S. (2009). Modeling the adoption and use of social media by nonprofit organizations. New Media \& Society, 15(2), 294-313.

Social Media Today (2019). Instagram stories is now being used by 500 million people daily. Available online at https://www.socialmediatoday.com/news/instagram-stories-is-nowbeing-used-by-500-million-people-daily/547270/

Startcounter (2019). Social media stats Nigeria. Retrieved from: https://gs.statcounter.com/ social-media-stats/all/nigeria

The Punch. (2003, April 18). Godfather and godson rift deepen in Kwara. Editorial.

Thrall, A. T., Stecula, D., \& Sweet, D. (2014). May we have your attention please? Humanrights NGOs and the problem of global communication. The International Journal of Press/ Politics, 19(2), 135-159.

Twitter (2012). Twitter turns six. https://blog.twitter.com/2012/twitter-turns-six

Udodiong, I. (2019). Here is how Nigerians are using the Internet in 2019. https://www.pulse. ng/bi/tech/how-nigerians-are-using-the-Internet-in-2019/kz097rg

USA Today (2014). How Facebook changed our lives. https://www.usatoday.com/story/ tech/2014/02/02/facebook-turns-10-cultural-impact/5063979/

USA Today (2018). Twitter overcounted active users since 2014, shares surge on profit hopes. https:// www.usatoday.com/story/tech/news/2017/10/26/twitter-overcounted-active-users-since2014-shares-surge/801968001/

Uzuegbunam, A. O. (2013). Non-governmental organizations (NGOs), conflict and peace building in Nigeria. Open Journal of Philosophy 3 (1), 207-212

Waters, R., \& Feneley, K. L. (2013). Virtual stewardship in the age of new media: have nonprofit organizations' moved beyond Web 1.0 strategies? International Journal of Nomprofit Voluntary Sector Marketing, 18 (3), 216-230.

Waters, R., Burnett, E., Lamm, A., \& Lucas, J. (2009). Engaging stakeholders through social networking: how nonprofit organizations are using Facebook. Public Relations Review, 35 (2), 102-106.

Webster, N., \& Fallows, B. S. (2006). Webster's encyclopedic dictionary. United States: Federal Street Press. 